\title{
ENVIRONMENTAL IMPLICATION OF METAL CONCENTRATIONS IN SOIL, PLANT FOODS AND POND IN AREA AROUND THE DERELICT UDEGE MINES OF NASARAWA STATE, NIGERIA
}

\author{
M.O. Aremu*, B.O. Atolaiye and L. Labaran \\ Department of Chemistry, Nasarawa State University, PMB 1022, Keffi, Nigeria
}

(Received August 13, 2009; revised February 8, 2010)

\begin{abstract}
Levels of sodium, potassium, nickel, copper, magnesium, iron, calcium, zinc, lead, cadmium, arsenic, selenium, chromium, manganese and tin were determined in soil, plant foods and pond located in Udege abandoned tin/columbite mining area of Nasarawa State, Nigeria. The mean concentration values of $\mathrm{Na}, \mathrm{K}, \mathrm{Ni}$, $\mathrm{Cu}, \mathrm{Mg}, \mathrm{Fe}, \mathrm{Ca}, \mathrm{Zn}, \mathrm{Pb}, \mathrm{Cd}, \mathrm{As}, \mathrm{Se}, \mathrm{Cr}, \mathrm{Mn}$ and $\mathrm{Sn}$ in the soils were: 10.69, 9.94, 0.04, 0.34, 4.55, 256.33, $209.89,1.02,0.20,1.60,1.19,5.03,46.79$ and $1.03 \mathrm{mgkg}^{-1}$ dry weight, respectively, while Cd was not at detectable range of atomic absorption spectrophotometer. Most metals from the soil were more highly concentrated than the corresponding values in the plant foods harvested in the same soil; samples showed evidence of bioaccumulation. Metal values of the plant foods harvested in the mining area and the ones harvested in non-mining area (control) fall within acceptable range. However, some toxic trace metals in the water sample from the pond were found to have contained concentrations above the permissible safe level. This pond should not be used as a source of potable water and other domestic purposes in the area.
\end{abstract}

KEY WORDS: Udege tin/Columbite mining area, Soil, Plant foods, Pond

\section{INTRODUCTION}

Chemical analysis of soil is important for environmental monitoring and legislation [1]. It provides information on the fertility status, index of nutrient availability and bases for fertilizer recommendation (for a given crop) as well as planning of a nutrient management programme. Metals are introduced into aquatic systems as a result of the weathering of rocks and soils, for example, volcanic eruptions and also from several human activities involving the mining, processing and uses of metals and industrial materials that contain metal contaminants [2]. Soil, whether in urban or agricultural areas represent a major sink for metals released into the environment from a variety of anthropogenic activities. These metals are not biodegradable and can undergo global ecological circles in which natural waters serve as the main pathways [3]. Natural waters are extremely complex chemical environments. Apart from dissolved and particulate matter, they contain dissolved organic matter of largely unknown compositions and almost every element in the periodic table [4]. Uncontrolled mining activities and illegal mining in developing countries have left a lot of environmental hazards and enormous amount of wastes and different types of pollutants are generated [5]. Crops provide nutritional needs of both man and animals. Man in turn also consumes the animals.

Tinstone or cassiterite (the ore of tin) and columbite are obtained from alluvial deposits associated with the younger granites which are only found in the northern states of Nigeria including those in Udege of Nasarawa State, Nigeria. Columbite, the ore of niobium, is derived from the older granite pegmatites commonly occurs as massive dull, iron-black lumps and crystals, containing varying amounts of tantalum. Mechanized mining in Nigeria started around 1939 through private owned foreign companies. The first legislation on mining was enacted in 1946 and was only reviewed in 1999 [6]. For many years tin/columbite were being mined under the supervision of the defunct Nigeria Mining Corporation, thus mechanized mining had been in practice for long time in Udege area [7]. Mechanized mining was abandoned at Udege area in

*Corresponding author. E-mail: lekearemu@gmail.com 
1980s due to the collapse of big mining companies in the early 70s, thus negative environmental impact is significant. The mining activities have left behind devastated landscape, exposed fertile lands, artificial dams, paddocks and abandoned ponds. It has also endangered the life of both flora and fauna in Udege area. The abandoned mining ponds are in most cases filled with water. These ponds are however, useful during dry season where they are used for irrigation, fish farming, livestock and domestic uses. Intensive farming is being practiced on the abandoned mining land by the local farmers with cowpea (Vigna unguiculata), bambara groundnut (Vigna subterranean), maize (Zea mays), guinea corn (Sorghum bicolor) and groundnut (Arachis hypogea) as major planting crops. These were the crops investigated while similar crops from Nasarawa (non-tin/columbite mining area), a neighbouring town in the same local government, were used as the control food crops for the study.

The study reported in this paper seeks to obtain more comprehensive data on the concentrations of 15 metals ( $\mathrm{Na}, \mathrm{K}, \mathrm{Ni}, \mathrm{Cu}, \mathrm{Mg}, \mathrm{Fe}, \mathrm{Ca}, \mathrm{Zn}, \mathrm{Pb}, \mathrm{Cd}, \mathrm{As}, \mathrm{Se}, \mathrm{Cr}, \mathrm{Mn}$ and $\mathrm{Sn}$ ) in the soil, five major food crops and a pond using as a source of potable water from Udege derelict tin/columbite mining area in Nigeria. Physicochemical properties of the water collected from the pond were also investigated. This type of work is important since the edible crops planted around the derelict tin/columbite mining area have the ability to bioaccumulate and biotransfer harmful minerals to ruminants that serve as protein sources to human beings and/or direct consumption of the plant crops as sources of food. In addition potable water supply to communities in Nasarawa State is the responsibility of the government which in most cases has been characterized by low productivity, small coverage and inefficient service delivery. Nasarawa Local Government Area is one of the areas that do not enjoy potable water supply. Most rural dwellers therefore depend on various available water sources including pond from the Udege tin/columbite mining area. However, it is well established that one of the primary anthropogenic sources of heavy metals is mines [8] thus emphasizing the important of this study.

\section{EXPERIMENTAL}

\section{Sampling}

Samples were taken from farms located in the abandoned tin/columbite mining Udege area of Nasarawa local government, Nasarawa State, Nigeria (Figure 1). An auger was used to take soil samples from the surface down to a depth of about $15 \mathrm{~cm}$ at various locations. Five different food crops of the same varieties as mentioned above were randomly harvested from the farms within each location at peak of the harvest by making arrangement with the respective farm owners. Similar crops were also harvested at the control site in Nasarawa. Harvesting period is between August and November 2008 of the same year. These were stored in polythene bags. Water sample was taken from a pond located in the abandoned mining area between August 2008 and March 2009 on a monthly basis. This was done in order to cover both wet and dry seasons. The samples were taken in pre-cleaned 1 litre polythene plastic kegs and acidified ( $\mathrm{pH}$ 1.5) with Analar grade concentrated nitric acid. They were kept in ice chests and transported to the laboratory. The water sample temperature was taken immediately at the site of collection using a simple thermometer calibrated in degree Celcius, $\mathrm{pH}$ was measured using a BNC $\mathrm{pH}$ meter (UK) and electrical conductivity was measured using conductivity meter model NATOP PB5 (China). The water samples were then stored in the deep freezer $\left(-4{ }^{\circ} \mathrm{C}\right)$ until further analyses were carried out. 


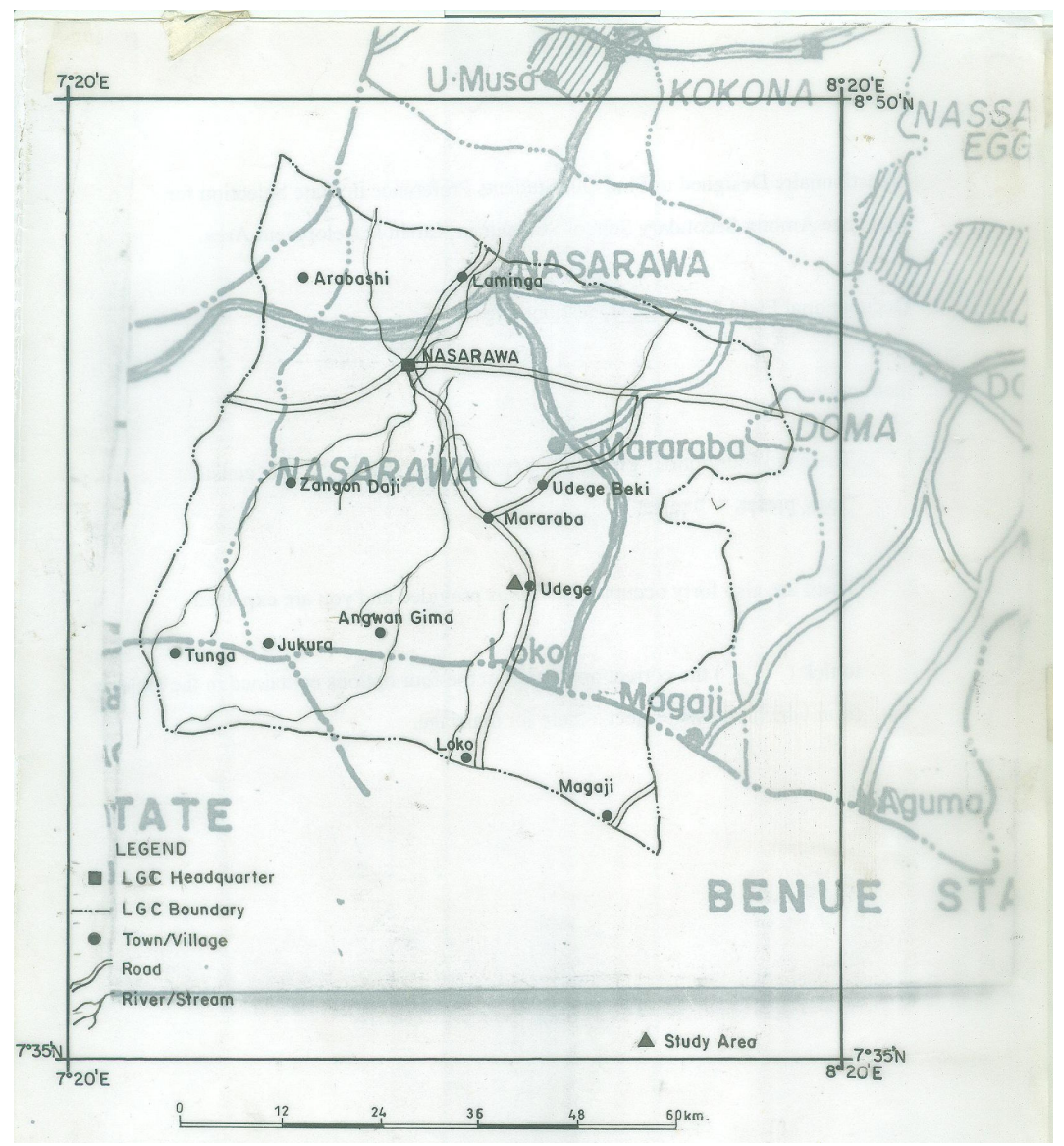

Figure 1. Map of Nasarawa showing Udege as study area.

\section{Sample treatment}

Once in the laboratory, the soil and plant crop samples were air dried. After drying, the soil particles were ground into fine particles using the laboratory mortal and pestle. The fine soil particles were sieved using a $200 \mathrm{~mm}$ mesh sieve. The finer soil particles were packed in samples bottles and labelled. Each crop sample was oven dried at $105{ }^{\circ} \mathrm{C}$ for $2 \mathrm{~h}$. The dried samples were then milled into powder using Author Thomas milling machine, sieved as above and appropriately labelled. A portion, $0.5 \mathrm{~g}$, of each soil and crop samples was weighed using Metler balance AE 160 weighing machine (UK) in $50 \mathrm{~mL}$ Pyrex glass beakers. Concentrated $\mathrm{HCl}, \mathrm{HNO}_{3}, \mathrm{HClO}_{4}$ and $\mathrm{HF}$ were added in that order to each of the samples in $5 \mathrm{~mL}$ applications. The beakers containing each of the samples were placed on the heater for about 3 $\mathrm{h}$ [9]. For the liquid sample, $5 \mathrm{~mL}$ of concentrated hydrochloric acid was added to $250 \mathrm{~mL}$ of water and evaporated to $100 \mathrm{~mL}$. The concentrate was transferred into a labelled bottle container after cooling [10].

Bull. Chem. Soc. Ethiop. 2010, 24(3) 
The concentrations of $\mathrm{Ni}, \mathrm{Cu}, \mathrm{Mg}, \mathrm{Fe}, \mathrm{Ca}, \mathrm{Zn}, \mathrm{Pb}, \mathrm{Cd}, \mathrm{As}, \mathrm{Se}, \mathrm{Cr}, \mathrm{Mn}$ and $\mathrm{Sn}$ in the three matrices (soil, food crop and water samples) were determined with an atomic absorption spectrophotometer (Buck scientific 200A model London, UK). Those of $\mathrm{Na}$ and $\mathrm{K}$ were determined with a flame photometer (Corning, Model 405, Gallenkamp, London, UK) using $\mathrm{NaCl}$ and $\mathrm{KCl}$ to prepare the standards [11]. Determinations were made on dry weight (DW) basis for all the samples.

Other physico-chemical parameters determined in the water samples were; alkalinity and total hardness by titrimetry method [12], chloride ion was measured by chloride ion meter (Model KRK, Cl-5Z Japan), phosphate (molybdophosphoric blue colour method in $\mathrm{H}_{2} \mathrm{SO}_{4}$ system) and nitrate were estimated using a PYE UNKPM visible spectrophotometer, (London, UK) total dissolved solids by gravimetric method and chemical oxygen demand (COD) by APHA method [12]. All the chemicals used were of analytical reagent grade and obtained from British Drug Houses (BDH, London).

Names of towns (as appropriate) were used in the various Tables whereas 1, 2, 3 were used to represent three different zones where the soil samples were collected.

\section{Statistical analysis}

All the data generated were analysed statistically [13]. Parameters evaluated were grand means standard deviation and coefficient of variation. All the determinations were in triplicate.

\section{RESULTS AND DISCUSSION}

Levels of metals in three different zones of Udege tin/columbite mining area are shown in Table 1. Calcium was the most concentrated of the major metals in all the three soils with values of 209.89, 26.15 and $53.50 \mathrm{mgkg}^{-1}$ dry weight (DW) for soil -1 , soil -2 and soil -3 , respectively, while potassium $\left(9.94 \mathrm{mgkg}^{-1} \mathrm{DW}\right)$, potassium $\left(8.70 \mathrm{mgkg}^{-1} \mathrm{DW}\right)$ and sodium $\left(4.69 \mathrm{mgkg}^{-1}\right.$ DW) in that order were the lowest in that group; among the trace metals iron was the highest in all the three soils with values of $256.33,249.73$ and $257.63 \mathrm{mgkg}^{-1} \mathrm{DW}$, respectively, while nickel $\left(0.04 \mathrm{mgkg}^{-1} \mathrm{DW}\right)$, copper $\left(0.69 \mathrm{mgkg}^{-1} \mathrm{DW}\right)$ and copper $\left(0.69 \mathrm{mgkg}^{-1} \mathrm{DW}\right)$ occupied the lowest position in the respective soils. Cadmium was not at detectable range of AAS in all the soil samples. The coefficient of variation percent $(\mathrm{CV} \%)$ for all the metal analysed in the soils ranged between $1.65 \%$ for iron to 116.72 for magnesium. The order of variation is $\mathrm{Mg}>\mathrm{Ca}>$ $\mathrm{Zn}>\mathrm{Pb}>\mathrm{Ni}>\mathrm{Mn}>\mathrm{Cu}>\mathrm{Na}>\mathrm{K}>\mathrm{Cr}>\mathrm{As}>\mathrm{Sn}>\mathrm{Se}>\mathrm{Fe}$.

Table 2 shows the metal content levels in the planted crops of Udege mining area. The most concentrated metals in Vigna unguiculata, Vigna subterranean, Zea mays, Sorghum bicolor and Arachis hypogea were Ca (74.02 $\left.\mathrm{mgkg}^{-1} \mathrm{DW}\right), \mathrm{Mg}\left(48.95 \mathrm{mgkg}^{-1} \mathrm{DW}\right), \mathrm{Mg}\left(48.94 \mathrm{mgkg}^{-1} \mathrm{DW}\right)$, $\mathrm{Ca}\left(72.21 \mathrm{mgkg}^{-1} \mathrm{DW}\right)$ and $\mathrm{Ca}\left(92.76 \mathrm{mgkg}^{-1} \mathrm{DW}\right)$, respectively, while $\mathrm{Mg}\left(28.65 \mathrm{mgkg}^{-1} \mathrm{DW}\right)$, $\mathrm{Ca}\left(25.47 \mathrm{mgkg}^{-1} \mathrm{DW}\right), \mathrm{Mg}\left(55.13 \mathrm{mgkg}^{-1} \mathrm{DW}\right), \mathrm{Ca}\left(22.52 \mathrm{mgkg}^{-1} \mathrm{DW}\right)$ and $\mathrm{K}\left(53.74 \mathrm{mgkg}^{-1}\right.$ DW), respectively, were the most concentrated metals in the similar food crops planted on nontin/columbite mining area (Table 3). The lowest concentrated metals in the same order for food crops in the mining area were $\mathrm{Cr}\left(0.01 \mathrm{mgkg}^{-1} \mathrm{DW}\right), \mathrm{Mn}\left(0.02 \mathrm{mgkg}^{-1} \mathrm{DW}\right)$, As $\left(0.08 \mathrm{mgkg}^{-1}\right.$ DW), Sn $\left(0.05 \mathrm{mgkg}^{-1} \mathrm{DW}\right)$ and Se $\left(0.09 \mathrm{mgkg}^{-1} \mathrm{DW}\right)$ (Table 2) while that of non-mining area were As (0.01 mgkg $\left.{ }^{-1} \mathrm{DW}\right), \mathrm{Mn}\left(0.04 \mathrm{mgkg}^{-1} \mathrm{DW}\right), \mathrm{As}\left(0.3 \mathrm{mgkg}^{-1} \mathrm{DW}\right), \mathrm{Ni}\left(0.09 \mathrm{mgkg}^{-1} \mathrm{DW}\right)$ and Mn (0.03 $\left.\mathrm{mgkg}^{-1} \mathrm{DW}\right)$ (Table 3). Cadmium in all the food samples, lead in Sorghum bicolor and Arachis hypogea, and manganese in Zea mays were not at the detectable range of AAS for food crops grown in the mining area while metals that were not detected in all the food crops from non-mining area were lead, cadmium and tin. 
Table 1. Metal concentration $\left(\mathrm{mgkg}^{-1}\right)$ of soil in Udege tin/columbite mining area of Nasarawa State, Nigeria.

\begin{tabular}{|l|l|l|l|l|l|l|}
\hline Metal & Soil-1 & Soil-2 & Soil-3 & Mean & SD & CV\% \\
\hline $\mathrm{Na}$ & $10.69(0.10)$ & $9.12(0.00)$ & $4.69(0.10)$ & 8.17 & 3.11 & 38.08 \\
\hline $\mathrm{K}$ & $9.94(0.10)$ & $8.70(0.40)$ & $14.06(0.00)$ & 10.90 & 2.81 & 25.73 \\
\hline $\mathrm{Ni}$ & $0.04(0.20)$ & $0.56(0.30)$ & $0.86(0.10)$ & 0.47 & 0.42 & 89.27 \\
\hline $\mathrm{Cu}$ & $0.34(0.30)$ & $1.17(0.20)$ & $0.69(0.01)$ & 0.73 & 0.41 & 56.63 \\
\hline $\mathrm{Mg}$ & $4.55(0.50)$ & $0.49(0.03)$ & $0.78(0.60)$ & 1.94 & 2.26 & 116.72 \\
\hline $\mathrm{Fe}$ & $256.33(0.40)$ & $249.73(0.05)$ & $257.63(0.10)$ & 254.56 & 4.24 & 1.65 \\
\hline $\mathrm{Ca}$ & $209.89(0.30)$ & $26.15(0.02)$ & $53.50(0.20)$ & 96.51 & 99.14 & 102.72 \\
\hline $\mathrm{Zn}$ & $1.02(0.10)$ & $9.70(0.20)$ & $21.74(0.10)$ & 10.82 & 10.41 & 96.17 \\
\hline $\mathrm{Pb}$ & $0.20(0.01)$ & $2.46(0.01)$ & $0.98(0.20)$ & 1.21 & 1.14 & 94.82 \\
\hline $\mathrm{Cd}$ & $\mathrm{ND}$ & $\mathrm{ND}$ & $\mathrm{ND}$ & -- & -- & -- \\
\hline $\mathrm{As}$ & $1.60(0.10)$ & $1.69(0.10)$ & $1.84(0.01)$ & 1.71 & 0.12 & 6.83 \\
\hline $\mathrm{Se}$ & $1.19(0.01)$ & $1.14(0.02)$ & $1.07(0.10)$ & 1.13 & 0.06 & 5.35 \\
\hline $\mathrm{Cr}$ & $5.03(0.10)$ & $4.79(0.05)$ & $3.10(0.20)$ & 4.31 & 1.05 & 24.41 \\
\hline $\mathrm{Mn}$ & $46.79(0.30)$ & $21.54(0.01)$ & $8.71(0.01)$ & 25.68 & 19.38 & 75.47 \\
\hline $\mathrm{Sn}$ & $1.03(0.20)$ & $0.90(0.10)$ & $1.45(0.00)$ & 1.13 & 0.07 & 6.41 \\
\hline
\end{tabular}

Numbers in parenthesis are standard deviations of triplicate determinations. Notes: ND $=$ not detected, $\mathrm{SD}=$ standard deviation, $\mathrm{CV} \%=$ coefficient of variation percent.

Table 2. Metal concentration $\left(\mathrm{mgkg}^{-1}\right)$ of five different crops planted in Udege tin/columbite mining area of Nasarawa State, Nigeria.

\begin{tabular}{|l|l|l|l|l|l|}
\hline Metal & V. unguiculata & V. subterranea & Z. Mays & S. bicolor & A. hypogea \\
\hline $\mathrm{Na}$ & $5.67(0.20)$ & $4.44(0.10)$ & $3.72(0.30)$ & $21.14(0.50)$ & $20.50(0.60)$ \\
\hline $\mathrm{K}$ & $4.56(0.10)$ & $3.65(0.00)$ & $3.24(0.01)$ & $9.96(0.01)$ & $10.49(1.50)$ \\
\hline $\mathrm{Ni}$ & $0.74(0.20)$ & $0.96(0.50)$ & $1.04(0.50)$ & $3.58(0.10)$ & $3.92(0.20)$ \\
\hline $\mathrm{Cu}$ & $1.23(0.10)$ & $0.73(1.00)$ & $2.05(0.20)$ & $0.60(0.00)$ & $1.11(0.30)$ \\
\hline $\mathrm{Mg}$ & $48.92(1.00)$ & $48.95(0.90)$ & $48.94(0.05)$ & $35.77(0.30)$ & $53.87(0.50)$ \\
\hline $\mathrm{Fe}$ & $4.58(0.00)$ & $0.65(0.01)$ & $0.61(0.10)$ & $6.66(0.20)$ & $8.31(0.10)$ \\
\hline $\mathrm{Ca}$ & $74.02(1.00)$ & $38.00(1.50)$ & $8.66(0.60)$ & $72.21(0.50)$ & $92.76(0.20)$ \\
\hline $\mathrm{Zn}$ & $8.24(0.10)$ & $3.76(0.20)$ & $6.69(0.50)$ & $5.92(0.10)$ & $5.46(0.10)$ \\
\hline $\mathrm{Pb}$ & $0.19(0.05)$ & $0.23(0.00)$ & $0.32(0.01)$ & $\mathrm{ND}$ & $\mathrm{ND}$ \\
\hline $\mathrm{Cd}$ & $\mathrm{ND}$ & $\mathrm{ND}$ & $\mathrm{ND}$ & $\mathrm{ND}$ & $\mathrm{ND}$ \\
\hline $\mathrm{As}$ & $1.00(0.40)$ & $0.35(0.23)$ & $0.08(0.20)$ & $0.50(0.10)$ & $0.56(0.20)$ \\
\hline $\mathrm{Se}$ & $0.11(0.01)$ & $0.22(0.05)$ & $0.20(0.20)$ & $0.82(0.10)$ & $0.09(0.20)$ \\
\hline $\mathrm{Cr}$ & $0.01(0.03)$ & $0.77(0.20)$ & $1.36(0.01)$ & $0.89(0.20)$ & $1.36(0.10)$ \\
\hline $\mathrm{Mn}$ & $0.52(0.03)$ & $0.02(0.02)$ & $\mathrm{ND}$ & $0.58(0.20)$ & $0.96(0.10)$ \\
\hline $\mathrm{Sn}$ & $0.06(0.20)$ & $0.06(0.10)$ & $0.10(0.20)$ & $0.05(0.10)$ & $0.75(0.20)$ \\
\hline
\end{tabular}

Numbers in parenthesis are standard deviations of triplicate determinations. ND $=$ not detected.

Iron was the most abundant in the soil samples determined with values ranging from 249.73 to $256.63 \mathrm{mgkg}^{-1} \mathrm{DW}$ (Table 1). The observation here confirms that most soils contain appreciable quantities of iron [14]. However, the concentration was low in the plant crops grown in the area. $\mathrm{Fe}^{3+}$ will be carried by acidic solutions but a slight increase in hydroxyl ion concentration would result in its precipitation as the hydroxide thereby making it unavailable. If a solution contained $\mathrm{Fe}^{2+}$ and $\mathrm{Mn}^{3+}$ then the following reaction is possible:

$$
\mathrm{Fe}^{2+}{ }_{(\mathrm{aq})}+\mathrm{Mn}^{3+}{ }_{(\mathrm{aq})} \leftrightarrow \mathrm{Fe}^{3+}{ }_{(\mathrm{aq})}+\mathrm{Mn}^{2+}{ }_{(\mathrm{aq})}
$$


and the values for $\mathrm{Fe}^{2+}$ suggest that it would indeed proceed to the right [12]; thus will further reduce the level of iron in solution. Iron is an essential nutrient for humans; hence, appropriate content of iron in food crops is essential for good health.

The tin levels were generally low with values ranging from $0.05 \mathrm{mgkg}^{-1} \mathrm{DW}$ in Sorghum bicolor to $0.75 \mathrm{mgkg}^{-1} \mathrm{DW}$ in Arachis hypogea in the food crops planted in the mining area (Table 2). Tests have shown that considerable quantities of tin can be consumed without effect on the human system [15]. Small amounts are present in most liquid canned products; its limit in foods is $300 \mathrm{mgkg}^{-1}$ in the USA and $286 \mathrm{mgkg}^{-1}$ in the UK which far exceeds the amount found in canned products of good quality [16].

The relatively high concentrations of $\mathrm{Fe}, \mathrm{Zn}, \mathrm{Pb}, \mathrm{As}, \mathrm{Mn}$ and $\mathrm{Sn}$ in the food crops planted in the mining areas compared with the ones in non-mining areas is an indication of presence of heavy metal pollution due to the mining activities in Udege area. Lead enters the food chain through consumption of lead bearing food stuffs and through inhalation. It has been found that one third of daily lead intake occurs through inhalation and the remaining two thirds from diet, this leads to lead accumulation in the body causing toxicity. The name given to the disease caused by lead poison is plumbism or saturninism [17]. A blood concentration above $2 \mu \mathrm{molL}^{-1}$ suggests undue exposure and is associated with the risk of developing lead poisoning [17]. All the Udege food samples were low in lead (Tables 2 and 3).

Table 3. Metal concentration $\left(\mathrm{mgkg}^{-1}\right)$ of five different food crops planted in Nasarawa (non-mining area) of Nasarawa State, Nigeria.

\begin{tabular}{|l|l|l|l|l|l|}
\hline Metal & V. unguiculata & V. subterranea & Z. mays & S. bicolor & A. hypogea \\
\hline $\mathrm{Na}$ & $18.50(0.20)$ & $25.64(1.00)$ & $17.12(0.10)$ & $11.54(0.10)$ & $22.62(0.01)$ \\
\hline $\mathrm{K}$ & $27.12(0.10)$ & $35.63(0.20)$ & $20.14(0.01)$ & $21.71(0.00)$ & $53.74(0.03)$ \\
\hline $\mathrm{Ca}$ & $25.73(0.01)$ & $43.14(0.01)$ & $55.13(0.02)$ & $22.52(0.20)$ & $53.57(0.20)$ \\
\hline $\mathrm{Mg}$ & $28.65(0.02)$ & $25.47(0.10)$ & $30.50(0.01)$ & $23.1(0.00)$ & $50.55(0.01)$ \\
\hline $\mathrm{Fe}$ & $1.75(0.01)$ & $0.84(0.01)$ & $0.56(0.10)$ & $3.73(0.01)$ & $4.50(0.10)$ \\
\hline $\mathrm{Ni}$ & $0.43(0.03)$ & $0.16(0.04)$ & $0.15(0.05)$ & $0.09(0.05)$ & $0.56(1.00)$ \\
\hline $\mathrm{Cu}$ & $0.05(0.01)$ & $0.34(0.01)$ & $1.70(0.05)$ & $0.81(0.03)$ & $0.08(0.00)$ \\
\hline $\mathrm{Zn}$ & $1.03(0.02)$ & $0.56(0.50)$ & $0.09(0.00)$ & $0.25(0.20)$ & $1.05(0.10)$ \\
\hline $\mathrm{Pb}$ & $\mathrm{ND}$ & $\mathrm{ND}$ & $\mathrm{ND}$ & $\mathrm{ND}$ & $\mathrm{ND}$ \\
\hline $\mathrm{Cd}$ & $\mathrm{ND}$ & $\mathrm{ND}$ & $\mathrm{ND}$ & $\mathrm{ND}$ & $\mathrm{ND}$ \\
\hline $\mathrm{As}$ & $0.01(0.01)$ & $0.05(0.01)$ & $0.03(0.10)$ & $0.45(0.20)$ & $0.05(0.01)$ \\
\hline $\mathrm{Se}$ & $0.21(0.04)$ & $0.07(0.10)$ & $0.05(0.50)$ & $0.83(0.00)$ & $0.11(0.01)$ \\
\hline $\mathrm{Cr}$ & $1.03(0.01)$ & $0.53(0.50)$ & $0.06(0.01)$ & $0.19(0.10)$ & $0.23(0.04)$ \\
\hline $\mathrm{Mn}$ & $0.73(0.30)$ & $0.04(0.00)$ & $1.00(0.01)$ & $0.81(0.00)$ & $0.03(0.05)$ \\
\hline $\mathrm{Sn}$ & $\mathrm{ND}$ & $\mathrm{ND}$ & $\mathrm{ND}$ & $\mathrm{ND}$ & $\mathrm{ND}$ \\
\hline
\end{tabular}

Numbers in parenthesis are standard deviations of triplicate determinations. ND $=$ not detected.

Comparison of metal content levels in the soils and plant crops in Tables 1 and 2 would show that all the metals determined were either more concentrated in the soils or compare favourably with ones in plant crops on a pair wise basis. This meant that the soils would serve as a reservoir source of all the metals in the environment. However, all the metal content levels determined in the soils were within the worldwide background contents of metals range [18]. The metal levels in the pond located in the abandoned mining area are presented in Table 4 . The highest concentrated metal was sodium $\left(3.10 \mathrm{mgkg}^{-1}\right)$ while the lowest was $\mathrm{Sn}\left(0.05 \mathrm{mgkg}^{-1}\right)$. $\mathrm{Cd}$ and $\mathrm{Mn}$ were not in the detectable range of AAS. 
Table 4. Metal concentration $\left(\mathrm{mgkg}^{-1}\right)$ of a pond in Udege tin/columbite mining area in Nasarawa State, Nigeria.

\begin{tabular}{|l|l|l|l|}
\hline Metal & Pond & USEPA $\left(\mathrm{mgL}^{-1}\right)$ & FEPA $\left(\mathrm{mgL}^{-1}\right)$ \\
\hline $\mathrm{Na}$ & $3.10(0.00)$ & NA & NA \\
\hline $\mathrm{K}$ & $1.78(0.50)$ & NA & NA \\
\hline $\mathrm{Ni}$ & $1.15(0.01)$ & 0.05 & $0.02-0.10$ \\
\hline $\mathrm{Cu}$ & $0.13(0.02)$ & 1.00 & $2.0-4.0$ \\
\hline $\mathrm{Mg}$ & $0.44(0.01)$ & NA & NA \\
\hline $\mathrm{Fe}$ & $0.98(0.02)$ & 0.30 & 1.0 \\
\hline $\mathrm{Ca}$ & $1.68(0.01)$ & NA & NA \\
\hline $\mathrm{Zn}$ & $1.33(0.02)$ & 2.0 & 50 \\
\hline $\mathrm{Pb}$ & $0.44(0.01)$ & 0.015 & 1.0 \\
\hline $\mathrm{Cd}$ & $\mathrm{ND}$ & 0.005 & $0.2-1.80$ \\
\hline $\mathrm{As}$ & $0.12(0.02)$ & 0.05 & 0.50 \\
\hline $\mathrm{Se}$ & $0.44(0.01)$ & 0.01 & NA \\
\hline $\mathrm{Cr}$ & $0.43(0.02)$ & 0.10 & $0.02-2.0$ \\
\hline $\mathrm{Mn}$ & ND & 0.05 & $0.02-0.10$ \\
\hline $\mathrm{Sn}$ & $0.05(0.01)$ & NA & NA \\
\hline
\end{tabular}

Numbers in parenthesis are standard deviations of triplicate determinations. Note: ND $=$ not detected, NA $=$ not available.

Minerals are very necessary for life [19-20]. The values obtained for sodium and potassium fall within the WHO/USEPA guidelines [21]. Sodium controls body water balance and plays a role in muscle contraction. Potassium spares sodium in the human body and its concentration in food when higher than sodium has a nutritional advantage. Calcium and magnesium content for each sample in the present study are within the WHO recommended range [22], indications that the water is desirable for drinking without any adverse effect on consumers. Calcium helps in blood clotting, in muscles contraction and in certain enzymes in metabolic processes. It has as a coordinator among inorganic elements; when potassium, magnesium or sodium is in excess in the body, calcium is capable of assuming a corrective role [23]. Magnesium is the second element contributing to both carbonate and non-carbonate hardness in water usually at a high concentration much lower than that of the calcium component. Magnesium is essential for bone formation, for reproduction and for normal functioning of the nervous system and it is also known to be a part of the enzyme system [24]. But when calcium and magnesium are in excess, they are undesirable in domestic water due to the problem of scale formation. Lead concentration level of the pond was $0.44 \mathrm{mgkg}^{-1}$. Lead even at low concentration is known to be toxic and has no known function in biochemical process. It can impair the nervous system and affect foetus, infants and children resulting in lowering of intelligent quotient (IQ) even at its lowest dose [25]. The onset of lead pollution of surface waters in Nigeria has been reported [26]. Lead sticks to soil particles and enters drinking water only if the water is acidic or soft and from the result presented in Table 5, Udege tin/columbite mining pond showed acidity with $\mathrm{pH}$ of 6.81. However, lead content value in the present study is higher than USEPA guideline [26] recommended value of $0.05 \mathrm{mgL}^{-1}$. $\mathrm{Cu}$ and $\mathrm{Zn}$ are essential metals and play an important role in enzyme activity [27]. Selenium content $\left(0.44 \mathrm{mgkg}^{-1}\right)$ is higher than the recommended value of a lethal dose in food between 0.1 and $0.5 \mu \mathrm{gg}^{-1}$ [17]. Some of the diseases caused by Se to mammals include accumulation of fluid throughout the body and destructive damage to the liver. The early symptoms of acute toxic effects of Se are sore throat, fever, vomiting, irritation to eyes and nose, headache, gastro-intestinal irritation, sleepiness or drowsiness; drop in blood pressure, dermatitis and garlic odour of the breath [28]. Arsenic level $\left(0.12 \mathrm{mgkg}^{-1}\right)$ in Udege water sample is higher than USEPA recommended value $\left(0.05 \mathrm{mgL}^{-1}\right)$ [26]. Arsenic has been 
implicated in lung cancer, especially when the arsenic compound inhaled is of low solubility. It has also been found to have an effect on the liver by causing a disease termed cirrhosis and a rare form of liver cancer called haemongioendothelioma [29]. Chromium level was $0.43 \mathrm{mgkg}^{-1}$, the metal is essential for life. Its deficiency results in diabetic mellitus and increases the toxicity of lead [15]. The $\mathrm{Zn}, \mathrm{Cu}, \mathrm{Mn}$ and $\mathrm{Sn}$ content in the pond water sample analysed were found to be within the permissible limits of WHO/USEPA and Canadian government standards [26]. Similar observation was made with the Federal Ministry of Environmental water standards for aquatic life to which most metals conform [30]. However, because a metal concentration in the aquatic environment is low and considered to be naturally occurring or background, does not mean that the concentration could not cause adverse ecological effects [26]. The presence of one metal can significantly affect the impact that another metal may have on an organism. The effect can be synergistic, additive or antagonistic [21]. Iron content is higher in the water sample and higher than the permissible level of USEPA guideline for drinking water (Table 4). Iron facilitates the oxidation of carbohydrates, proteins and fats. It therefore contributes significantly to the prevention of anaemia. Iron also plays an important role in the oxidative processes of respiration in living organism and also for normal functioning of the central nervous system [31]. It has been reported that iron overload can cause liver toxicity and increase the risk of liver failure or hepatocellular caranions in humans [32]. The presence of high concentration of iron in our water sample is unacceptable for consumption and not only that, high content of iron in water could give to iron-dependent bacteria which in turn can cause further deterioration in the quality of water by the production of slimes or objectionable odour [33], again emphasizing the importance of this type of study.

Table 5. Physico-chemical properties of a pond in Udege tin/columbite mining area in Nasarawa State, Nigeria.

\begin{tabular}{|l|l|l|l|}
\hline Parameter & Water sample & Permissible criteria & Desirable criteria \\
\hline $\mathrm{pH}$ & $6.81(4.05)$ & $6.0-8.5$ & $6.0-8.5$ \\
\hline Temperature $\left({ }^{\circ} \mathrm{C}\right)$ & $25.33(1.02)$ & NA & Na \\
\hline Phosphate $\left(\mathrm{mgL}^{-1}\right)$ & ND & $0.01-0.05$ & 0.01 \\
\hline Chloride $\left(\mathrm{mgL}^{-1}\right)$ & $0.40(0.01)$ & 2.50 & $<25$ \\
\hline Nitrate $\left(\mathrm{mgL}^{-1}\right)$ & ND & $<10$ & Virtually absent \\
\hline Bicarbonate $\left(\mathrm{mLL}^{-1}\right)$ & $11.94(2.01)$ & NA & NA \\
\hline Turbidity $(\mathrm{NTU})$ & $0.40(0.50)$ & NA & NA \\
\hline Conductivity & $0.64(0.15)$ & NA & NA \\
\hline Alkalinity $\left(\mathrm{mgL}^{-1}\right)$ & $1.14(0.20)$ & $30-500$ & $30-500$ \\
\hline Total dissolved solids TDS $\left(\mathrm{mLL}^{-1}\right)$ & $899.00(12.70)$ & 500 & $<200$ \\
\hline Chemical oxygen demand $(\mathrm{COD})\left(\mathrm{mgL}^{-1}\right)$ & $6.22(0.10)$ & NA & NA \\
\hline Total hardness $\left(\mathrm{mgL}^{-1}\right)$ & $2.99(1.05)$ & NA & NA \\
\hline
\end{tabular}

Numbers in parenthesis are standard deviations of triplicate determinations. Notes: ND = not detected; NA = not available. ${ }^{\text {a }}$ Source $=$ Report of the committee on water quality criteria, Federal Water Pollution Administration, US Department of Interior, Washington, D.C., 1968 and Federal Protection Agency, Nigeria, 1988.

Table 5 shows physico-chemical parameter levels of water samples from the pond located in Udege tin/columbite mining area. Phosphate and nitrate were not present. The $\mathrm{pH}$ is a function of the dissolved material in water and should be less than 8.5 [26]. The $\mathrm{pH}$ in this report is low (6.8) which implies that the pond is acidic and may not be favourable to the existence of bacteria in the pond. The temperature values $\left(25.33{ }^{\circ} \mathrm{C}\right)$ comply with WHO recommended value of $25{ }^{\circ} \mathrm{C}$. Turbidity is a function of the suspended matter in water which ranged from colloidal to coarse dispersion while chemical oxygen demand (COD) is used for estimating the concentration of organic matter in wastewaters. The values of turbidity $(0.40 \mathrm{NTU})$ and COD 
(6.22 $\mathrm{mgL}^{-1}$ ) obtained in this report showed that the pond was not seriously polluted because high value of COD implies that such water will have objectionable odour, render the water unfit for domestic purpose and reduce oxygen available for aquatic organisms. Chloride concentration was $0.4 \mathrm{mgL}^{-1}$. Chlorides occur in natural water at varying concentrations depending on the geochemical conditions. Chlorides are the most stable components in water with concentration that is unaffected by most natural physicochemical or biochemical processes; their amount in water is useful measure in water samples. Chloride can range from $<10 \mathrm{mgL}^{-1}$ to $>2500 \mathrm{mgL}^{-1}$ (in sea water) [34].

\section{CONCLUSIONS}

This work has presented metal concentrations ( $\mathrm{Na}, \mathrm{K}, \mathrm{Ni}, \mathrm{Cu}, \mathrm{Mg}, \mathrm{Fe}, \mathrm{Ca}, \mathrm{Zn}, \mathrm{Pb}, \mathrm{Cd}, \mathrm{As}, \mathrm{Se}$, $\mathrm{Cr}, \mathrm{Mn}$ and $\mathrm{Sn}$ ) in Vigna unguiculata, Vigna subterranean, Zea mays, Sorghum bicolor and Arachis hypogea planted and harvested in Udege tin/columbite mining area of Nasarawa State, Nigeria. Metal concentrations of the soils as well as ponds of the mining area were also presented. The results revealed that there was an indication of some heavy metals pollution in the old mining area although values of these metals are within acceptable range. The study further revealed that water from the abandoned pond located in the mining area was not desirable for drinking because of the presence of some toxic trace metals above the permissible safe level. This work therefore will serve as baseline information for future work.

\section{REFERENCES}

1. Carter, M.R. Soil Sampling and Methods of Analysis, Canadian Society of Soil Science: Lewis Bola Carter, FL.; 1993; pp. 40-75.

2. Gutenmann, W.H.; Bach, C.A.; Mccahan, J.B.; List, D.I. Nutr. Rep. Int. 1988, 38, 1157.

3. Adekola, F.A.; Salami, N.; Lawal, S.O. Res. Comm. Chem. 2000, 1, 24.

4. Turner, D.R. in Pollution: Causes, Effects and Control, Harrison, R.M. (Ed.), 2nd ed., Royal Society of Chemistry: London; 1981; pp. 1-200.

5. Onyedika, G.O.; Nwosu, G.U. Pak. J. Nutr. 2008, 7, 418.

6. Obaje, N.G.; Lar, U.A.; Nzegbuna, A.I.; Moumouni, A.; Chaanda, M.S.; Goki, N.G. Nasara Scientifique, 2005, 2, 9.

7. Aliyu, A.A.; Aluko, B.A.; Biliaminu, K.O. Priority investment projects in the solid minerals sector, Raw Materials Research and Development Council, Abuja Bulletin, 1996; pp. 67173.

8. Goyer, R.A. Toxic Effects of Metals in Casaret and Doull's Toxicology: Basic Science of Poisons, Klaasen, C.D. (Ed.), McGraw Hill: New York; 1996; p 120.

9. Udo, E.J.; Ogunwale, A.J. Laboratory Manual for the Analysis of the Soils, Plant and Water Samples, Department of Agronomy, University of Ibadan: Ibadan, Nigeria; 1978; pp. 7076.

10. Parker, R.C. Water Analysis by Atomic Absorption Spectoscopy, Varian Techtron: Geneva; 1972, pp. 15-39.

11. Association of Official Analytical Chemists (AOAC) Official Methods of Analysis, AOAC: Washington, DC; 968.08, 1990.

12. American Public Health Association (APHA) Standard Methods for the Examinations of Water and Wastewaters, 19th ed., American Public Health Association (APHA), New York; 1995.

13. Steel, R.G.D.; Torrie, J.H. Principles of Procedures of Statistics, McGraw Hill: London; 1960; pp. 1-360. 
14. Satcliffe, J.F.; Baker, F.A. Plants and Mineral Salts: Studies in Biology No 48, Adward Arnold (Publishers) Limited: London; 1974.

15. Othmer, K. Encyclopedia of Chemical Technology. Vol. 20, 2nd ed., John Wiley and Sons: London; 1969, pp. 195- 199.

16. Monier-Williams, G.W. Trace Elements in Food, John Wiley and Sons: New York; 1950; pp. 138-161.

17. Ademoroti, C.M.A. Environmental Chemistry and Toxicology, Foludex Press Ltd.: Ibadan, Nigeria; 1996, pp. 186-204.

18. Kabata-Pendias, A.; Pendias, H. Trace Elements in Soils and Plants, 2nd ed., CRS Press: Baton Rouge, FL.; 1992, pp. 1-365.

19. Buss, D.; Robertson, J. Manual of Nutrition, 8th ed., Her Majesty's Stationery Office: London; 1976, pp. 32-40.

20. Aremu, M.O. in Environment, Health and Nutrition: Global Perspective, Basu, S.K.; Datta, B. (Eds.), A.P.H. Publishing Inc.: New Delhi, India; 2008, pp. 79-96.

21. Esler, R. Zinc Hazard to Fish, Wildlife and Invertebrates: A Review. US Fish and Wildlife Service, Biological Report 10 Publication Unit USFWS: Washington, DC; 1993.

22. World Health Organization Guideline for Drinking Water Quality, World Health Organization: Geneva; 1993.

23. Fleck, H. Introduction to Nutrition, 3rd ed., Macmillian: New York; 1976; pp. 207-219.

24. Shills, M.E.G.; Young, V.R. in Nutrition, Nieman, D.C.; Butterworth, D.E.; Nieman, C.N. (Eds.), Wm. C. Brown Publishers: Dubuque, USA; 1988; pp. 276-282.

25. United Nations (UN) Global Opportunities for Reducing use of Lead Gasoline, IOMC/UNEP/CHEMICALS/98/9: Switzerland; 1998

26. United States Environmental Protection Agency (USEPA) Current Drinking Water Standards, Office of Groundwater and Drinking water: Government Printing Office, Washington, D.C.; 2002.

27. National Academy of Sciences (NAS) in Introduction to Nutrition, Fleck, H. (Ed.), 3rd ed., Macmilliam Publishing Co. Inc.: New York; 1971, p 235.

28. Luckey, T.D.; Venugopal, B. Metal Toxicity in Mammals, Vols. I and II, Plenum Press: New York; 1977; p 78.

29. Hutton, M. in Lead, Mercury, Cadmium and Arsenic in the Environment, Hutchinson, T.C.; Meema, K.M. (Eds.), John Wiley and Sons: New York; 1987, pp. 85-94.

30. Federal Ministry of Environment (FME) National Guidelines and Standards for Water Quality in Nigeria, Federal Ministry of Environment: Nigeria; 2001.

31. Vyas, D.; Chandra, R.K. Discov. Innov. 1984, 11, 75.

32. Messner, D.J.; Swan, G.; Kowdley, K.V. Liver International 2008, 29, 63.

33. Aremu, M.O.; Sangari, D.U.; Musa, B.Z.; Chaanda, M.S. Int. J. Chem. Sci. 2008, $1,8$.

34. Templeton, R.G. Freshwater Fisheries Management Fishing, News Book Ltd.: Famham, London; 1984; p. 183. 